\title{
高圧水素容器への急速水素充てん中の伝熱特性*
}

門 出 政 則 ${ }^{* 1}$,
Peter WOODFIELD ${ }^{* 3}$, 丸 武 雄 一 $^{* 2}$ 晋 一 $^{* 4}$

\section{Characteristics of Heat Transfer and Temperature Increase of Hydrogen during Filling at High Pressure}

\author{
Masanori MONDE*5, Yuhichi MITSUTAKE, \\ Peter WOODFIELD and Shinichi MARUYAMA \\ *5 Department Mechanical Engineering, Saga University, \\ 1 Honjo-machi, Saga-shi, Saga, 840-8502 Japan
}

\begin{abstract}
An experiment has been made to measure the rise in temperature of a gas during filling a tank at high pressure. The experimental condition is that filling gases are Nitrogen and Hydrogen at a pressure of 5 to $35 \mathrm{MPa}$ and at a filling mass of $G=45$ to $324 \mathrm{~g} / \mathrm{min}$ for Hydrogen. The temperatures are measured either horizontally or vertically at five positions in the tank. It is found that heat loss transferred from compressed gas to the tank wall has a significant effect on the rise in the filled gas temperature. The heat transfer coefficient is estimated after the end of filling and is about $\alpha_{h}=270$ $\mathrm{W} /\left(\mathrm{m}^{2} \mathrm{~K}\right)$ for the Hydrogen at $35 \mathrm{MPa}$. A theoretically procedure is proposed to calculate the temperature increase of the gas on a basis of assumption that the gas temperature in the tank is uniform at any time, and the heat transfer coefficient is given. The calculation shows that the temperature is in reasonable agreement with the measured temperatures by assuming $\alpha_{h}=500$ $\mathrm{W} /\left(\mathrm{m}^{2} \mathrm{~K}\right)$ during the filling of hydrogen at $35 \mathrm{MPa}$, although the estimated heat loss after the end of filling becomes larger than the actual one.
\end{abstract}

Key Words : Hydrogen Filling, Measurement of Temperature Increase, Storage of Hydrogen, High Pressure

\section{1. はじめに}

水素は，高いエクセルギー効率をもっていることか ら 2 次エネルギーとして最近注目されているのみなら ず, 燃料電池の普及につれて広く利用されることが期 待されている. 特に, エネルギー効率の改善や都市の 大気環境保全という視点から燃料電池自動車 $(\mathrm{FCV}$ : Fuel Cell Vehicle)の普及が図られ，公道での実証試験 も行われているという状況下にあって，燃料である水 素の貯蔵方式として目下高圧水素貯蔵が主流となって いる. 燃料貯蔵タンクにはアルミニウムライナー・カ 一ボン FRP 複合容器やプラスチックライナー・カー ボンFRP 複合容器などが使用されている.

しかし, これらの素材は, 温度が高くなると脆化す るため, 水素充てん時の水素温度の上昇と容器温度の 上昇が容器の安全設計上大きな問題となる.

最近, 実規模タンクを用いた $35 \mathrm{MPa}$ 水素充てん中 の水素の温度や容器への外気温の変化に対する測定結 果が報告(1)されているが, 熱工学の視点からの検討が

* 原稿受付 2005 年 7 月 13 日.

*1 フェロー, 佐賀大学理工学部 (巨 840-8502 佐賀市本庄町 1).

*2 正員, 佐賀大学理工学部.

*3 佐賀大学博士特別研究員

*4 (財) エンジニアリング振興協会 (恶 105-0003 東京都港区西 新橋 1-4-6).

E-mail : monde@me.saga-u.ac.jp
十分なされているとは言い難い，一方，窒素充てん中 の窒素温度の変化について, 伝熱工学的視点からの検 討(2)が行われているが，気体を理想気体として取り扱 っている. そして, 窒素と容器との熱伝達率として, 充てん終了時で $31.4 \mathrm{~W} /\left(\mathrm{m}^{2} \mathrm{~K}\right)$ 程度の值を推奨している. 本研究では, $35 \mathrm{MPa}$ 以下の水素を試験容器に急速 充てんしたときの容器内の水素温度の測定および容器 壁の温度を測定した結果およびそれらの変化から水素 から容器壁への伝熱量について気体と固体の連成問題 であるという視点から検討した結果を報告する．更に， 充てん中の水素の温度と容器の温度を推定するための 簡易方法を提案する。

\section{主要 祀 号}

$\begin{array}{ll}A & : \text { タンク内表面積 } \\ h_{\mathrm{a}} & : \text { 充てんされる気体のエンタルピー } \\ G & : \text { 充てん質量流量 } \\ m & : \text { タンク内の質量（充てん量） } \\ p & : \text { 圧力 } \\ q_{\mathrm{w}} & : \text { 表面熱流束 } \\ R & : \text { 気体定数 } \\ T & : \text { 温度 } \\ T_{\mathrm{g}} & : \text { 気体の温度 }\end{array}$




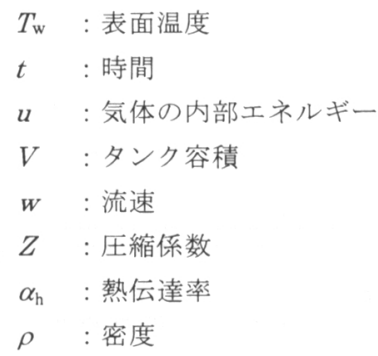

\section{2. 実験装置と実験方法}

2.1 実験装置図 1 は, 本実験装置の全体図を示 す.また, 図 2 は水素貯蔵タンク（材質：ステンレ ス）と温度測定点を示す. 水素の貯蔵タンクへの供給 は, $10 \mathrm{MPa}$ 以下については水素カードルタンクから,

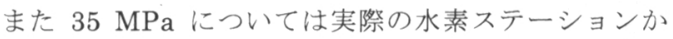
ら直接供給された。また, 水素との比較のために, 窒 素ガスによる充填も $10 \mathrm{MPa}$ 以下で行われている. 接続部の管径は, $\phi 10 \mathrm{~mm}$ である.

貯蔵タンクは, $\phi 93.7$ x $200 \mathrm{~mm}(\mathrm{~V}=1.38 \mathrm{~L})$ で, 供給側の容量と比較して無視できる体積となっている. この結果, 水素供給側の体積は, 無限の容量, 寸なわ ち供給される水素の圧力や温度は一定と見なすことが できる。

容器壁への伝熱量を定性的に把握するために, 断熱 材を容器内円筒部に設置するという実験も行った。

\section{2 测定方法と水素の充てんについて 充てん中} の容器内の温度は, 図 2 に示されるように中心軸上 (鉛直方向) に $37 \mathrm{~mm}$ 間隔で設置あるいは半径方向 に $10 \mathrm{~mm}$ 間隔で設置された 5 本の熱電対によって測 定されている．鉛直方向と半径方向の温度の測定は, それぞれ別個に行われている，本実験で使用した熱電 対は, シース径 $1 \mathrm{~mm}$ (素線径 $0.1 \mathrm{~mm}$ ) で, 風洞での検 定試験では, 空気の流速が $3.5 \mathrm{~m} / \mathrm{s}$ のとき, 約 5 秒後 に熱電対の指示温度は, 気体の温度の 0.86 の指示と なった. ところで, 熱電対の応答の早さは, 熱伝達率 の大きさに依存し, 流体側の流れ（流速や流路形状） の状況が同じ場合には, 気体の動粘性係数と熱伝導率 に支配される。そして, 流れが層流の場合, 概略 $\alpha_{\mathrm{H} 2} / \alpha_{\text {air }}=2.68$ となり, 空気温度の測定と比較して水 素に対する熱電対の指示温度はより早く応答すること が期待される。このような状況を考慮すると, 熱電対 の指示温度は, 数秒の時間遅れとなっていると考えら れる、また, 充てん中の圧力変化は動ひずみ計を用い て測定されている. 温度変化と圧力変化はサンプリン グ時間 0.1 秒で行われている. 測定開始時刻は, 弁の
開放時刻となっている，圧力については，時間の遅れ は無視できるが, 温度については熱電対の応答遅れの ほかに気体の流入の遅れがある。

供給流量の大まかな調整は, 弁の開度によって行っ た。正確な充てん量は, $m(t)=\rho(p(t), T(t)) V$ で, 密度 は, 充てん中の圧力と温度 (系内の平均温度) から実 在気体の式を用いて推定した。なお，実在気体のデー タベースとして文献[3,4]を利用した。 また, 流入速 度は, $w=\mathrm{d} m(t) / \mathrm{d} t /\left(\rho_{\mathrm{o}} S\right)\left(S\right.$ : 供給管断面積, $\rho_{\mathrm{o}}$ : 充て ん水素の容器入口での密度）から推定した。図 3 は, 充てん圧力 $40 \mathrm{MPa}$ から水素を充てんしたときの流 速の変化を示す. 図 3 に示されるように, 水素充てん 中の容器入り口速度は, 充てん開始直後かなり大きい 流入速度となっているが，急激に減少している。これ は, 圧力差の減少と圧力上昇に伴う密度の増大による ものである. また, 容器内では水素の急激な膨張と充 てん水素による圧縮仕事が生じている。

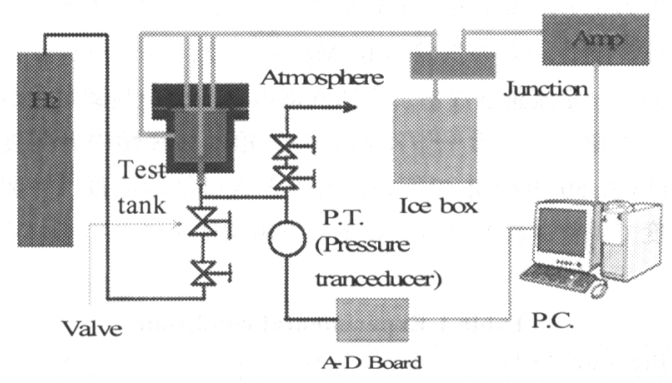

Fig. 1Schematic diagram of whole experimental apparatus Ф 198

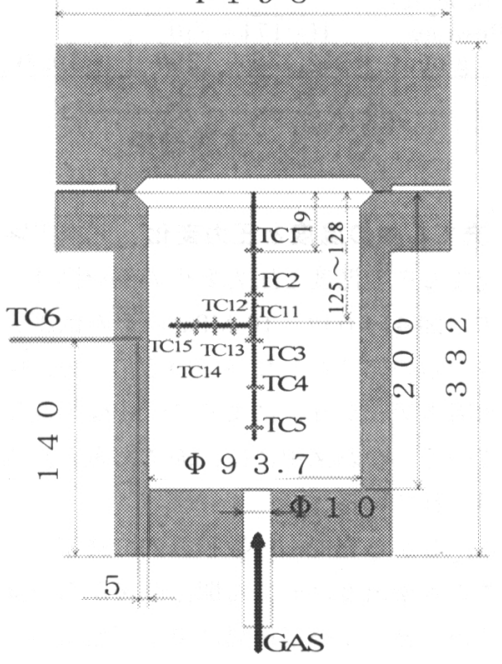

Fig.2 Main part of experimental apparatus 


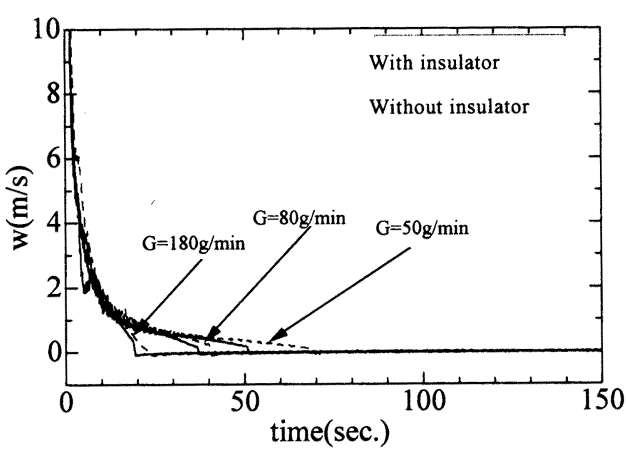

Fig. 3 Inlet velocity change during filling of $\mathrm{H}_{2}$

2.3 实験方法 容器内の気体を水素のみにするた めに数回パージを繰り返し, その後容器内の状態を周 囲と同じ圧力（大気圧）と温度に保つ. 供給側のバル ブを所定の開度に設定し，水素の供給を開始する，開 始と同時に, 温度や圧力の測定を行う. 充てん圧が所 定の圧力に達すると実験を終了する. なお, 水素ステ ーションからの供給（40 MPa）では, ステーション 側で一定流量となるように水素の供給量を制御しなが ら供給した。カードルからの供給は 3 種類の弁開度 (13.3, 50, $99 \%)$ で行い, そのときの供給流量は弁開 度で調整されている，表 1 に実験条件をまとめておく。

Table 1 Experimental condition

\begin{tabular}{|l|c|c|c|c|}
\hline Pressure $\mathrm{MPa}$ & $5-10$ & $5-35$ \\
\hline Gas & $\mathrm{H}_{2}$ and $\mathrm{N}_{2}$ & \multicolumn{2}{|c|}{$\mathrm{H}_{2}$} \\
\hline $\begin{array}{l}\text { Arrangement } \\
\text { of } \\
\text { thermocouples }\end{array}$ & vertical & radial & vertical & Radial \\
\hline $\begin{array}{c}\text { Gas flowrate } \\
\mathrm{g} / \mathrm{min}\end{array}$ & \multicolumn{2}{|c|}{$\begin{array}{c}\mathrm{H}_{2}: 174-330 \\
\mathrm{~N}_{2}: 438-1290\end{array}$} & $50,80,180$ \\
\hline
\end{tabular}

\section{3. 実験結果}

\section{1 充てん中の温度と压力㚆化 本実験で測定さ} れた充てん中の温度と圧力変化の例を図 4 から図 10 に示す. 図 4-6 は, $10 \mathrm{MPa}$ 以下の低圧充てんでカ 一ドルからの充てんとなっている. 一方, 図 7-10 は, 水素ステーションによる $35 \mathrm{MPa}$ の高圧充てんと なっている，なお図中には，充てん量と流入速度も同 時に示されている.

図 4，.5 から充てんは数秒以内で終了している.夕 ンク内の水素温度は充てん開始直後から急激に上昇し ているが，充てん終了後温度降下が始まっている．こ れは，充てんに伴う圧縮仕事が内部エネルギーに変換 されている間は気体の温度上昇となっているが, 終

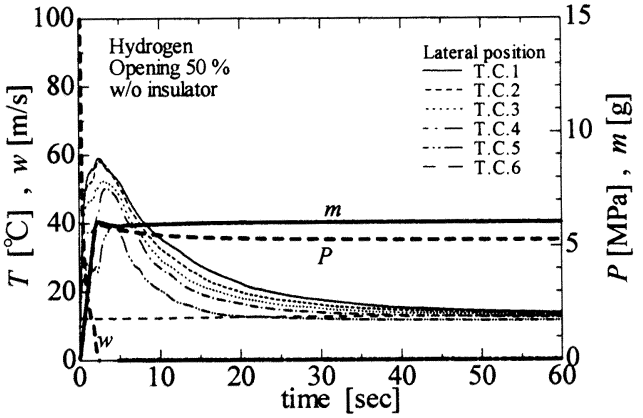

Fig.4 Change in temperature at lateral position and pressure during filling of $\mathrm{H}_{2}$ at pressure of $5 \mathrm{MPa}$ without insulator

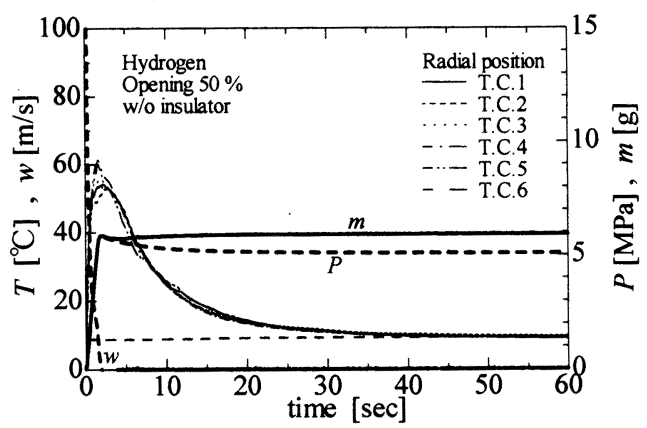

Fig.5 Change in temperature at radial position and pressure during filling of $\mathrm{H}_{2}$ at pressure of $5 \mathrm{MPa}$ without insulator

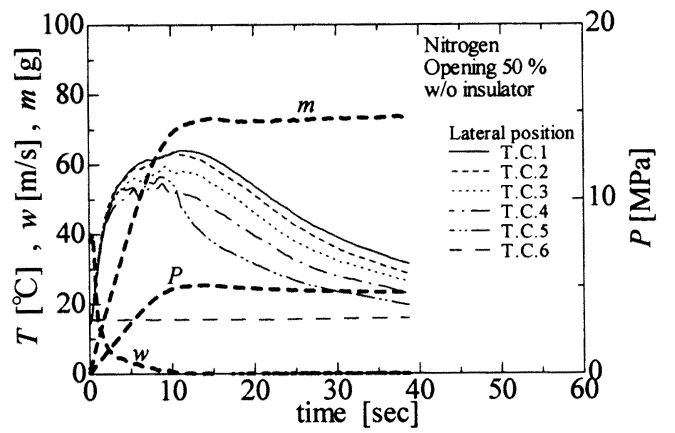

Fig. 6 Change in temperature at radial position and pressure during filling of $\mathrm{N}_{2}$ at pressure of $5 \mathrm{MPa}$ without insulator

了後は, 気体から容器への熱伝達によって気体の内部 エネルギーが減少し，温度が降下する，ところで，温 度変化の様子は鉛直方向と半径方向で大きく異なって いる，すなわち，鉛直方向の温度は流れの方向に熱電 対位置 TC1-3 の順で高くなっているが TC4, 5 では, ほぼ同じ温度変化となっている，そして，鉛直方向の 温度差は, 充てん終了後の温度降下中においてもその ままの状態で推移しながら徐々に同じ温度に漸近して 
いる，一方，半径方向の温度は，壁面に近いほど多少 高くなる傾向が見られるが，最終的にはほぼ同じ值と なっている. 特に, 充てん終了後では, 半径方向には 温度分布が殆ど現れていない。この結果，タンク内の 気体の温度はある程度成層を保ちながら温度変化して いると考えられる，そして，この成層化は，充てんさ れる水素の温度が容器内の水素温度より低くかつ圧力 が高いこと, 更に流入速度が急激に減少しているため によるものと推察される。

図 6 は，水素の充てんと同じ弁開度でかつ同じ充 てん圧力で窒素ガスを充てんしたときの温度と圧力の 変化を示す.

図 4，6の比較から，窒素の充てんは水素と比較 してかなり緩やかな圧力上昇となっている。これは， 分子量が 14 倍大きくなるので管路抵抗がおおきくな るためである。しかし，充てん終了時の上昇温度は， いずれの場合もほぼ同じで，約 $60^{\circ} \mathrm{C}$ となっている. また，鈶直方向の温度分布も水素の場合と同じ傾向を 示しているが, 温度降下は水素と比較して緩やかな温 度降下となっている．この相違は，気体とタンク壁間 の熱伝達の相違によるものである（詳細は 4 章で検 討).

また，充てんで昇温された気体から容器に熱は伝わ るが, $5 \mathrm{MPa}$ の充てんでは容器壁面の温度（TC6の温 度）はほんの少しの上昇に止まっている。これは，気 体の熱容量に比較して固体の熱容量が非常に大きいた めである.

$3.235 \mathrm{MPa}$ 充てんでの温度と压カの変化図 7, 8 は, $35 \mathrm{MPa}$ で水素を充てんしたときの鉛直方向と 半径方向の温度分布を示す. 2 種類の充てん速度での 結果が例示されている.

図 7 から, 充てん速度が大きくなると容器内の水素 の温度はより高くなることが分かる，また，温度の上 昇は, $\mathrm{G}=45,170 \mathrm{~g} / \mathrm{min}$ いずれの場合も水素の供給 孔に最も近い位置の温度が最小で，流れの方向に従っ て高くなっている.この傾向は, $5 \mathrm{MPa}$ の充てんと同 じである，しかし，充てん開始数秒後に大きな温度変

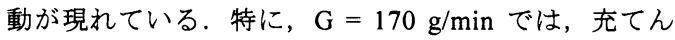
終了まで続いている，一方， G= $45 \mathrm{~g} / \mathrm{min}$ では供給孔 から遠い位置ほど温度変動は早く治まるが, 近い位置 の温度（TC5）は，充てん終了まで続いている．これ は, 密度の大きい水素が減速されながら（図 3 参照） 供給孔から充てんされることから供給された水素が上 方まで到達できなくなる，この結果，滑らかな温度変 化となっているところでは上部の水素温度がより高く なっている, すなわちより密度の小さい水素が滞留し
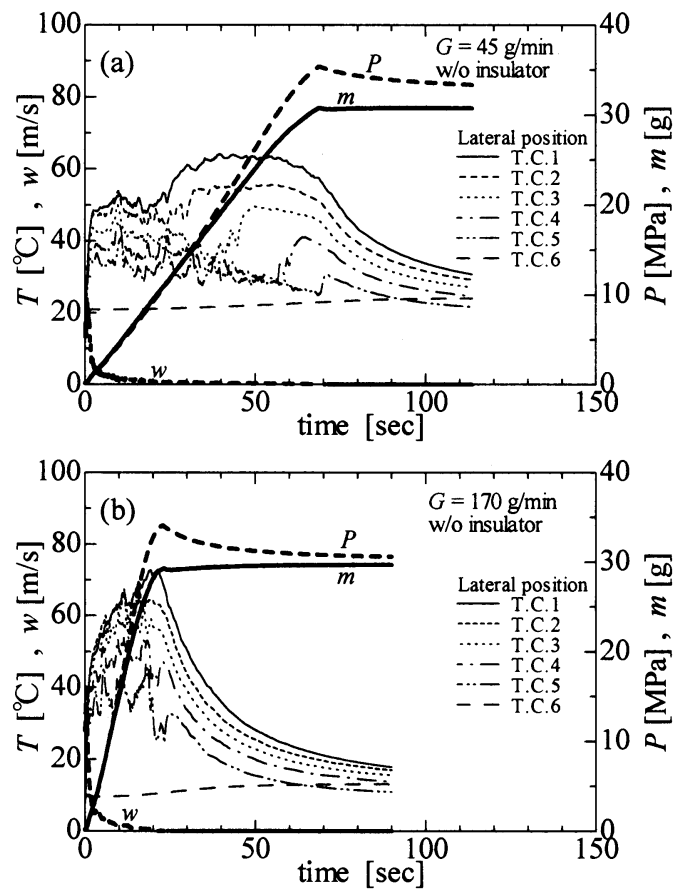

Fig. 7 Change in temperature at lateral position and pressure during filling of $\mathrm{H}_{2}$ at pressure of $35 \mathrm{MPa}$ without insulator

(a) $\mathrm{G}=45 \mathrm{~g} / \mathrm{min}$ (b) $\mathrm{G}=170 \mathrm{~g} / \mathrm{min}$
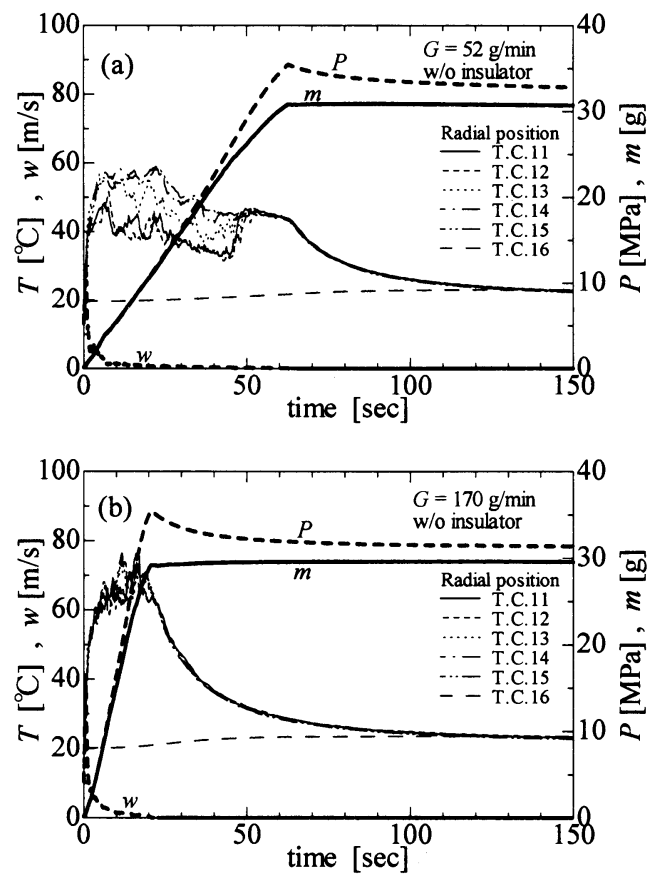

Fig. 8 Change in temperature at radial position and pressure during filling of $\mathrm{H}_{2}$ at pressure of $35 \mathrm{MPa}$ without insulator

(a) $\mathrm{G}=52 \mathrm{~g} / \mathrm{min}(\mathrm{b}) \mathrm{G}=170 \mathrm{~g} / \mathrm{min}$ 
ていることになることから安定な温度成層化がなされ ていると考えられる.

図8から, 半径方向の温度分布は, 壁面に近いほど 温度が高くなっている傾向が $\mathrm{G}=52 \mathrm{~g} / \mathrm{min}$ で見られる が, $\mathrm{G}=170 \mathrm{~g} / \mathrm{min}$ ではそれほど顕著ではない，これ は, $\mathrm{G}=170 \mathrm{~g} / \mathrm{min}$ では, 流速が大きいために容器内 に循環流が形成され, それによって温度の均質化が生 じたものと考えられる. また, 充てん終了後, G=52, $170 \mathrm{~g} / \mathrm{min}$ のいずれの場合も, 半径方向の温度分布が ほとんどなくなっている。

図 7,8 の温度変化から充てん終了後の冷却（水素 から容器一の伝熱) 過程は, 温度成層化された状態で 生じていると推測される.

3.3 断熟材の影雷 図 9 は, 容器内の円筒部に 3 $\mathrm{mm}$ ゴム板を断熱材として張り付けて水素を充てんし たときの温度変化の例である.

図 9 から鉛直方向と半径方向の温度変化の特性は断 熱材がない場合とほぼ同様な傾向となっているが, 各 点の温度は, 断熱材のないときの温度よりも約 $20^{\circ} \mathrm{C}$ 上昇している. また, 充てん後の泠却過程での温度降 下も断熱材のないときと比較してかなり緩やかになっ ている.これらは, 断熱材の顕著な効果のためである.

充てん中の水素の温度は, 充てん中の伝熱に大きく 依存していることが, 断熱材の効果から明らかである.

\section{4 容器壁への伝熟㙉充てんされた水素から夕} ンク壁への伝熱量は, $5 \mathrm{MPa}$ の充てんでは僅かな温 度上昇であったが, $35 \mathrm{MPa}, \mathrm{G}=170 \mathrm{~g} / \mathrm{min}$ では, 図 9 に示されるように水素の圧縮仕事も非常に大きくな り, 水素の温度もかなり上昇した。 その結果, 伝熱量 も大きくなり, 壁面の温度も図 7 に示されるように多 少上昇していることが分かる.

\section{5 重力の糟図 10 は, $5 \mathrm{MPa}$ の水素を下向}

き（供給孔を上部に設置）に供給したときの温度変化 を示す，温度の上昇幅は，いずれの場合も約 $50^{\circ} \mathrm{C}$ で ほぼ一致している，また，鉛直方向の温度分布も供給 孔から遠ざかるにつれて上昇している。しかし，充て 几終了後の温度分布は, 温度の逆転が生じている。こ れは, 温度が低く, 密度の高い水素が上部に滞在して いるために対流が発生したためである。温度の逆転後 は，温度分布が成層化され，緩やかな泠却となってい る. 図 10 と 4 を比較すると, 充てん終了後の泠却速 度は，供給孔が上にある方がより早く泠却されている。 これは, 対流の発生によって熱伝達の促進効果が生じ たためである.

\section{4. 温度推定の簡易方法}
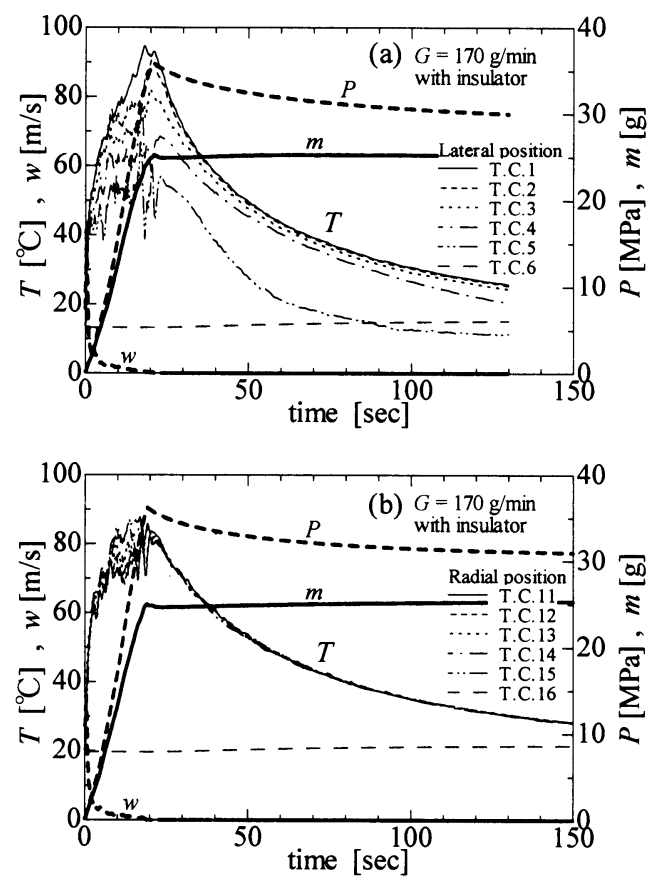

Fig.9 Change in temperature during filling of $\mathrm{H}_{2}$ at pressure of $35 \mathrm{MPa}$ with insulator

(a) lateral position (b) radial position

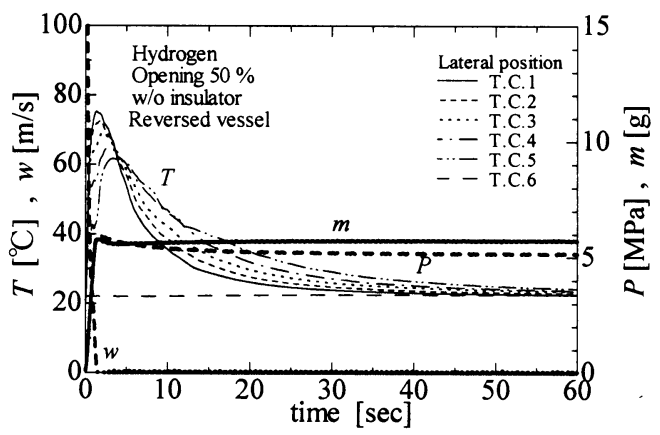

Fig. 10 Change in temperature during filling of $\mathrm{H}_{2}$ from the top of tank at pressure of $5 \mathrm{MPa}$ without insulator

水素充てん中の容器内の水素は, 鉛直方向に温度分 布を持ちかつ容器内を対流している，その対流の大き さは, 充てん速度や密度の変化に強く支配される。こ の結果, 充てん中の水素の温度は, 気体と固体の連成 問題でかつ非常に複雑な非定常現象となる.

そこで, 本実験では容器内の温度は鉛直方向に分 布しているけれども，簡易的に容器内の水素を集中定 数系 (容器内の状態が一様) として取り扱い, 充てん 中の水素の平均温度と容器の温度について検討する。

4.1 支眍方程式水素充てん中の水素に対するエ ネルギー式は, 次式となる. 


$$
\frac{d Q}{d t}+\dot{M} h_{a}=\frac{d}{d t}\left(m u\left(p, T_{g}\right)\right)
$$

初期温度は, タンク内で一様な温度とする。

$$
\left.T_{g}\right|_{t=0}=T_{0}
$$

質量保存則は，

$$
\dot{M}=d m / d t
$$

で, 初期質量は,

$$
\left.m\right|_{t=0}=V \rho_{0}
$$

となる。 また, タンク内の質量を密度で表すと，

$$
m=V \rho\left(p, T_{g}\right)
$$

実在気体の状態方程式を適用すると充てん中のタンク 内の水素密度は,

$$
\rho\left(p, T_{g}\right)=p / Z\left(p, T_{g}\right) R T_{g}
$$

となる。

式(1)の熱移動の項 $\mathrm{d} Q / \mathrm{d} t$ は, 一般に $\mathrm{d} Q / \mathrm{d} t=\alpha_{\mathrm{h}} A\left(T_{\mathrm{w}}\right.$ $\left.-T_{\mathrm{g}}\right)$ となる. 熱伝達率 $\alpha_{\mathrm{h}}$ は, 気体の熱伝導率と流れ の状態の関数で，測定によって与えられる。また， $T_{\mathrm{w}}$ は, 気体と固体との連成問題で固体内の熱伝導方 程式の解 ${ }^{(5)}$ から決定される。なお， $T_{\mathrm{w}}(t)$ が，時間の関 数となる場合には, Duhamel の定理（重㸚合わせの原 理）あるいはラプラス変換を利用して解く(5)ことにな る.

ところで，もし，熱伝達率 $\alpha_{\mathrm{h}}$ が既知であるなら， 未知の物理量, 水素の圧力 $p(t)$, 温度 $T_{\mathrm{g}}(t)$, 密度 $\rho(t)$, 充てん量 $m(t)$ あるいは容器の表面温度 $T_{w}(t)$ の いずれか 1 つの值が与えられると,これらの関係式か ら残りの值が全て決定される.

例えば，図 4-10 に示されるように，圧力が時間と 共に直線的に上昇する場合, その関係式は，

$$
p=p_{o}+\left(\left(p_{f}-p_{o}\right) / t_{f}\right) t
$$

となる.ここで， $p_{\mathrm{o}}$ は初期圧力， $p_{\mathrm{f}}$ は最終圧力， $t_{\mathrm{f}}$ は 充てん終了時間である.

もし, 熱伝達率 $\alpha_{\mathrm{h}}$ が与えられると, 温度 $T_{\mathrm{g}}(t)$, 充 てん量 $m(t)$ と温度 $T_{\mathrm{w}}(t)$ は, 式(1),(5),(6) と非定常熱 伝導の解との同時連立方程式の解として与えられる.

解は, 式 (6)の圧縮係数や積分形で与えられる熱伝導 解などのため陽に与えることが困難であることから数 値計算によって求められる.

4.2 熱伝達率の推定 熱伝達率の推定は, 以下の 事情から充てん終了後の気体の温度降下に注目するこ とにした。（1）充てん中，気体に圧縮仕事によるエネ ルギーの供給がある。（2）充てん中, 温度が大きく
脈動している.（3）充てん終了後, 気体の温度は一様 に降下し,この温度降下は, 気体が椧却されているこ とのみによる. 冷却中の温度変化は, 容器内の気体を 集中定数系であると仮定すると，次式となる.

$$
T_{g}-T_{w o}=C e^{-\left(\alpha_{h} A / m c_{v}\right) t}
$$

ここで， $T_{\mathrm{g}}$ は，測定温度の算術平均温度， $T_{\mathrm{wo}}$ は， 容器壁面温度, $A$ は表面積である。測定温度（TC6） は，図 4-10 に示されるように $1-2{ }^{\circ} \mathrm{C}$ 上昇している が推定された温度 $T_{\text {wo }}$ が水素の温度変化と比較してか なり小さいことからここでは充てん終了時の温度 （一定）で，代表することにした．なお，逆問題解の 解析から，壁面温度は，充てん終了時の温度よりもほ んの少し高くなっていることから，実際の温度差は， $\left(T_{\mathrm{g}}-T_{\mathrm{wo}}\right)$ の值よりも小さく, $\left(T_{\mathrm{g}}-T_{\mathrm{wo}}\right)<5{ }^{\circ} \mathrm{C}$ では $10 \%$ 以上の誤差となる.

図 11 は，式(8)を用いて $35 \mathrm{MPa} て ゙$ 水素充てん後 の泠却中の温度変化を整理した図である. 図 11 中の 破線は最小自乗法で求めた直線である。そして，この 直線の勾配が， $-\alpha_{\mathrm{h}} A / m c_{\mathrm{v}}$ と等しいことから，熱伝達 率 $\alpha_{\mathrm{h}}$ を求めることができる.

表 2 は，いろいろな充てん条件に対して熱伝達率を 推定した結果である。なお，質量流量については表 2 に示される流量範囲で， 3 種類の異なる流量で測定が 行われたが， $\alpha_{\mathrm{h}}$ の值は，あまり変化しなかったので， 表 2 に示されるように整理した。

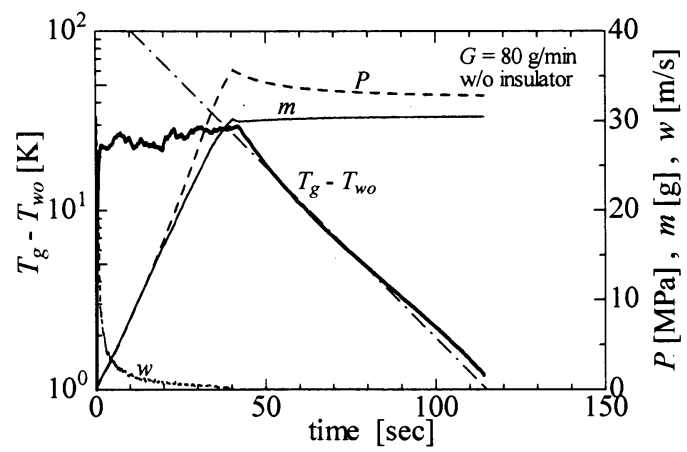

Fig. 11 Temperature difference between averaged and wall temperatures with time

Table 2 Heat transfer coefficient at various condition

\begin{tabular}{|c|c|c|c|}
\hline $\begin{array}{c}\mathrm{P} \\
\mathrm{MPa}\end{array}$ & & $\begin{array}{r}\text { Mass flow rate } \\
\mathrm{g} / \mathrm{min}\end{array}$ & $\begin{array}{c}\alpha_{\mathrm{h}} \\
\mathrm{W} / \mathrm{m}^{2} / \mathrm{K}\end{array}$ \\
\hline \multirow{2}{*}{5} & $\mathrm{H}_{2}$ & $168-276$ & $86.4-97.4$ \\
\cline { 2 - 4 } & $\mathrm{N}_{2}$ & $456-1296$ & $43.0-47.0$ \\
\hline \multirow{2}{*}{10} & $\mathrm{H}_{2}$ & $240-324$ & $143.1-154.5$ \\
\cline { 2 - 4 } & $\mathrm{N}_{2}$ & $732-996$ & $38.9-44.7$ \\
\hline 35 & $\mathrm{H}_{2}$ & $45-170$ & $269.7-279.2$ \\
\hline
\end{tabular}


表 2 から，熱伝達率は異なる充てん流量に対してほ ぼ同じ值となっているのは, 充てん終了後で流れの影 響が徐々に小さくなって行く状況で測定されているた めと考えられる. 従って, 充てん中で容器内に流れが ある状況下の熱伝達率は, ここで得られた熱伝達率よ りも当然大きい値となる.

表 2 から水素の熱伝達率は, 充てん圧力が大きくな ると熱伝達率が増大することが明らかになった．

ところで, 島本 ${ }^{(2)}$ は， $\mathrm{N}_{2}$ の充てん中の熱伝達率と して $\alpha_{\mathrm{h}}=31.4 \mathrm{~W} / \mathrm{m}^{2} / \mathrm{K}$ を推奖しているが, この值は本 測定結果と比較して多少小さめの值となっている.

\section{3 充てん水秦の温度変化の推定 熱伝達率の值} は, $35 \mathrm{MPa}$ での水素充てんでは少なくとも 270 $\mathrm{W} / \mathrm{m}^{2} / \mathrm{K}$ 以上となることが分かった。そこで,・1例と して熱伝達率 $\alpha_{\mathrm{h}}=250$ と $500 \mathrm{~W} / \mathrm{m}^{2} / \mathrm{K}$ と仮定したとき の充てん水素の温度変化と容器の温度変化の計算結果 を図 12 に示す.

図 12 から， $\alpha_{\mathrm{h}}=500 \mathrm{~W} / \mathrm{m}^{2} / \mathrm{K}$ で推定された温度は, 充てん中に測定された温度のほぼ平均的な值となって いるが, 一方充てん後の温度変化については推定温度 の降下の方が大きくなっていることが分かる．逆に， $\alpha_{\mathrm{h}}=250 \mathrm{~W} / \mathrm{m}^{2} / \mathrm{K}$ とすると, 推定温度は, 測定值よりも かなり高い值となっている. 一方, 容器の表面温度は いずれの場合でも大きな相違は見られない。これは, 十分な厚さの固体の熱容量が, 気体の熱量量と比較し て非常に大きいことによるものである，従って，固体 側から見ると，固体の熱容量は気体よりも一般に十分 大きい熱容量を持っているから, 気体の温度変動は, 固体温度にとって微小な影響しか及ぼしていない。こ の結果, 固体の温度を推定する上では，気体の温度変 動を無視した集中定数系として充てん中の伝熱特性を 把握しても, 設計上重大な問題とならないと思われる. なお,アルミニウム・カーボン FRP 複合容器などの 相対的に熱容量が小さい容器では, 温度の上昇が顕著 になる可能性がある. 容器と充てん水素の温度上昇は, 最終的には，充てん時に外部よりなされた仕事が両者 の内部エネルギ一増加, すなわち温度上昇として保存 されることになる．

\section{5.まとめ}

高圧気体のタンクへの急速充てん中の気体温度を測 定し，その特性を明らかにした。またここの温度変化 が気体とタンクとの熱的連成問題であるという視点か らモデルを提案した．提案されたモデルは，集中定数 系で行われているが, 気体の平均温度や容器の温度を
推定するのに十分な精度であることおよびモデルの妥 当性が検証された.

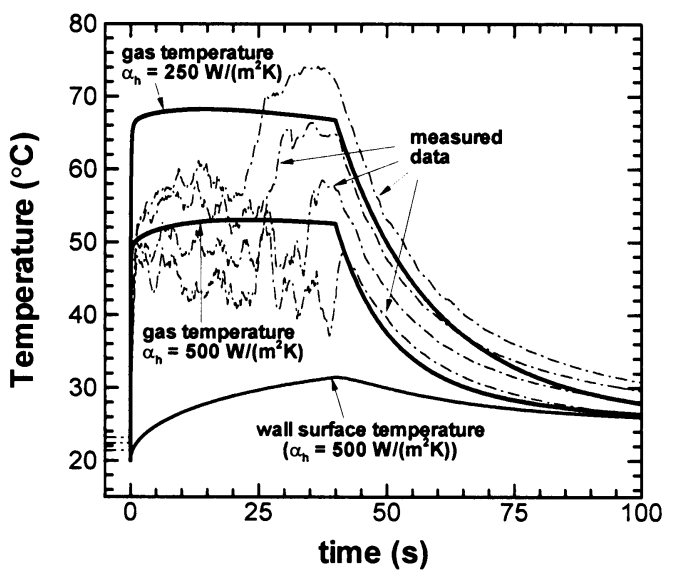

Fig.12 Comparison between estimated and measured temperatures

$(\mathrm{G}=80 \mathrm{~g} / \mathrm{min}, 35 \mathrm{MPa}$ and without insulator $)$

おわりに，本研究は新エネルギー・産業技術開発 機構からの受託研究として行われた。また，本研究を 推進するに当たって，太陽日酸株式会社の白根義和氏 と久和野敏明氏の協力を得た。ここに記して感謝する.

\section{文献}

(1) Kakihara, K. et al., Research on automobile, 26-6(2004) 295-298.

(2) Shimamoto, I., High Pressure Gas., 14-8, (1977) 1-6.

(3) Perry, R. H., et al., Perry's Chemical Engineering Handbook (7th ed.), Mc Graw-Hill 2-245

(4) Lee, B., I. And Kesler, M. G., AIChE J. 21-3, (1975), 510-527.

(5) Carslaw, H. S. and Jeager, J. C., Conduction of Heat in solid, Oxford Univ. press, (1959). 